\title{
Legal support of social responsibility of agribusiness entities of Ukraine
}

Apoyo legal de responsabilidad social de entidades agroindustriales de Ucrania

Apoio legal de responsabilidade social de entidades do
agronegócio da Ucrânia

Ganna Korniyenko

Received: March 3 ${ }^{\text {rd }}, 2021$

Accepted: April $4^{\text {th }}, 2021$

Published: July $6^{\text {th }}, 2021$

How to cite this article:

Ganna Korniyenko. Legal support of social responsibility of agribusiness entities of Ukraine. DIXI, vol. 23, n. 2, julio-diciembre 2021, 1-14. DOI: https://doi.org/10.16925/2357-5891.2021.02.11

Research article. https://doi.org/10.16925/2357-5891.2021.02.11

1 Ph.D. Associate Professor of Land and Agrarian Law Department, Yaroslav Mudryi National Law University, Kharkiv, Ukraine.

E-mail: gannakor1@hotmail.com

ORCID: https://orcid.org/0000-0002-70621027 


\section{Abstract}

Corporate social responsibility is a current issue for every European country, due to the implementation of the United Nations Guiding Principles on Business and Human Rights. For Ukrainian agribusiness, the issue of social responsibility becomes especially important as Ukraine is at the initial stage of formation of the land market. It is expected that investors will take part in the social development of rural areas. So, this must be taken into account when planning agrarian business in Ukraine. At the same time, the legal regulation of corporate social responsibility is still insufficiently developed, which determines the relevance of the topic of the article.

Keywords: Agribusiness, agrarian law, sustainable development, social responsibility, agrarian production.

\section{Resumen}

La responsabilidad social corporativa es un tema de actualidad para todos los países europeos, debido a la implementación de los Principios Rectores de las Naciones Unidas sobre Empresas y Derechos Humanos. Para la agroindustria ucraniana, la cuestión de la responsabilidad social se vuelve especialmente importante, dado que Ucrania se encuentra en la etapa inicial de formación del mercado de tierras. Se espera que los inversores participen en el desarrollo social de las zonas rurales. Por lo tanto, esto debe tenerse en cuenta al planificar negocios agrarios en Ucrania. Al mismo tiempo, la regulación legal de la responsabilidad social empresarial aún está insuficientemente desarrollada. Esto determina la relevancia del tema del artículo.

Palabras clave: agroindustria, derecho agrario, desarrollo sostenible, responsabilidad social, producción agraria.

\section{Resumo}

A responsabilidade social corporativa é uma questão atual para todos os países europeus, devido à implementação dos Princípios Orientadores das Nações Unidas sobre Empresas e Direitos Humanos. Para o agronegócio ucraniano, a questão da responsabilidade social torna-se especialmente importante, uma vez que a Ucrânia está na fase inicial de formação do mercado de terras. Espera-se que os investidores participem do desenvolvimento social do meio rural. Portanto, isso deve ser levado em consideração ao planejar negócios agrários na Ucrânia. Ao mesmo tempo, a regulamentação legal da responsabilidade social corporativa ainda não está suficientemente desenvolvida. Isso determina a relevância do tema do artigo.

Palavras-chave: agronegócio, direito agrário, desenvolvimento sustentável, responsabilidade social, produção agrária. 


\section{INTRODUCTION}

Corporate social responsibility is a modern issue for every European country, due to the implementation of the United Nations Guiding Principles on Business and Human Rights and of the United Nations Sustainable Development Agenda until 2030. Thus, in 2011 the United Nations Commission adopted an updated corporate social responsibility strategy, which combines horizontal approaches to promoting corporate social responsibility / business responsibility with more specific approaches for individual sectors and policies. Following its strategy, the Commission published a staff working document in March 2019.' These Principles have been discussed for six years and adopted in order to increase the role of entrepreneurship in the promotion and implementation of human rights, so that a gradual social sustainable globalization could be provided. ${ }^{2}$ Corporate social responsibility is especially popular in the field of agribusiness relations. This branch of entrepreneurial activity itself is most closely related to the social development of rural areas, vocational training of rural youth, and providing jobs for rural residents and participation in development programs of individual territorial communities.

The issue of social responsibility of agribusiness is of special importance for Ukraine, because Ukraine is at the initial stage of formation of the market for agricultural land. As a consequence of the opening of the land market, the question of social responsibility of agribusiness to agricultural communities also arises. In addition, it is expected that investors in the agricultural sector will participate in the social development of rural areas, which must be considered while planning agribusiness activity in Ukraine. At the same time, the legal regulation of corporate social responsibility is still insufficiently developed. It contains neither principles, nor directions. It also does not take into account the peculiarities of entrepreneurship in various sectors of the economy. The above emphasizes the relevance of the study of legal support of social responsibility of agribusiness entities of Ukraine.

That is why the purpose of the article is to identify the actual trends of formation and methodological justification of the legal support of social responsibility of agribusiness entities.

1 Corporate Social Responsibility \& Responsible Business Conduct. Available at: https:// ec.europa.eu/growth/industry/sustainability/corporate-social-responsibility_en 


\section{MATERIALS AND METHODS}

The main materials of this study are the norms of corporate social responsibility and its implementation into European Union company law, Ukrainian legislation in the field of rural social development. The study is also based on the analysis of statistical data on employment of the rural population in 2015-2019, hired rural workers in 2018, and existing socio-economic partnership agreements concluded between the local community and the agribusiness entities. The basic research methods are analysis, synthesis and generalization. They provided an opportunity to identify the state of European legislation as well as to analyze the possibility of its application and implementation in Ukrainian legislation. A systematic approach was used to identify a set of social problems of the Ukrainian countryside in the areas of corporate social responsibility of agribusiness entities. The application of the axiological method revealed the values of posthumous reproduction.

\section{LEGAL REGULATION OF SOCIAL RESPONSIBILITY}

Social responsibility of agribusiness is a modern and popular direction of society development. Globally, this responsibility is associated with the preservation of the environment, the cultivation of safe food, the spread of organic production, and the development of the social infrastructure of rural areas. If we turn to the European business support of the Common Agricultural Policy, according to the latter the development of these areas is aimed at state support. As a result, specific relations are formed among the state, society and business, which are based on mutual responsibility.

Since 2012, the Food and Agriculture Organization of the United Nations has determined that during the transition period of the agricultural sector of Ukraine's economy, living conditions in rural areas have deteriorated significantly: Unemployment has been spreading and household incomes have decreased, while the rural population continues to decline. The situation has been exacerbated by poor housing conditions, limited access to social, cultural and entertainment services, and the further spread of poverty. At the same time, agriculture remains the main source of income for rural residents, in which almost $17 \%$ of the economically active population is employed. ${ }^{3}$

3 T. Gagalyuk \& F. Schaft. CORPORATE SOCIAL RESPONSIBILITY IN AGRIBUSINESS. Kyiv. (2016). Pg. 8. 
The following statistical data also indicate the state of social development in rural areas of Ukraine. The number of employers in agriculture, forestry and fisheries (aged 15-70 years old) was: 2015 - 2,870.6 thousand people; 2016 - 2,866.5 thousand people; 2017 - 2,860.7 thousand people; 2018 - 2,937.6 thousand people; $2019-3,010.4$ thousand people. ${ }^{4}$ According to the level of admission and dismissal of employees in agriculture, forestry and fisheries in 2018, 53.9 thousand people were hired and 51.4 thousand were fired. ${ }^{5}$ These figures emphasize that the agricultural sector of the economy is in the stage of active development. It should be borne in mind that industry in Ukraine is declining, and therefore the liberated population is looking for employment in the market of agricultural production.

After all, agribusiness entities and investors in agriculture of Ukraine need to consider that rural settlements significantly lose to cities in a number of indicators, including income-expenditure, consumer property characteristics, the level of housing, transport infrastructure development, quality of education, and health care and consumer services. At the same time, the poverty of the rural population is much higher than in the urban population, and this important problem needs to be solved. Villagers are no longer poor in terms of monetary characteristics, but primarily in terms of deprivation of access to social facilities and infrastructure, as well as the quality of housing. ${ }^{6}$ This situation is typical of Mexican farmers, where poverty, passed down from generation to generation, perpetuates the process of internal migration to urban centers, the richest states, and for many in the United States as undocumented agricultural workers. ${ }^{7}$ Therefore, the social responsibility of agribusiness entities must be realized in all countries of the world. It creates an opportunity to form a prosperous rural society, and to overcome the social problems of rural areas.

The presence of social problems of rural development in Ukraine leads to the fact that the primary issue of social responsibility of agribusiness entities is the social development of rural areas. In contrast, in other European countries corporate social responsibility of agribusiness is aimed at other factors, in particular improving the environmental friendliness of production. Thus, in Germany agribusiness enterprises experience high external public pressure regarding the use of GMOS, environmental

4 Statistical Data. Agriculture, Forestry and Fisheries in Ukraine. Available at: http://www. ukrstat.gov.ua/druk/publicat/kat_u/publ7_u.htm Portillo Abril \& C. Rosales. Agribusiness, Corporate Social Responsibility, and Health of Agricultural Migrant Workers. FRONTIERS IN PUBLIC HEALTH. 2016. Available at: https:// doi.org/10.3389/fpubh.2016.00054 
factors and the specific product characteristics. External pressure leads to critical scrutiny of corporate goals and the activities of agricultural producers. German agricultural companies care about their social responsibility: They want to be known for conscientious behavior, and emphasize the constant development of professional qualities of staff; they are involved in environmental protection issues; they cooperate in the framework of social initiatives and participate in the development of social and environmental standards; they apply mixed responsibility (corporate volunteering). ${ }^{8}$ In other words, the social responsibility of European agribusiness is linked to a "good name" based on efforts to increase competition, distribute products to consumers who are interested in providing safe products and supporting businesses that care about the environment and society. This approach is the future of the relationship between Ukrainian society and agricultural producers. The prospects for this are due to the fact that social responsibility is a broader direction than the support of rural areas.

As for social responsibility, Ukrainian researchers consider it from various aspects:

- The obligation of the organization to function as an economically, socially and environmentally conscious company;

- Commitment to business development in order to influence society in a positive way;

- Balance of interests of all stakeholders;

- Participation in various activities and use of resources without fraud;

- Formation of social and environmental problems as part of the profit process. $^{9}$

It follows from the above that social responsibility in Ukraine, in particular in the field of agribusiness, is considered through an understanding of the obligation. However, this obligation is social in nature. It is concluded within the framework of socio-economic agreements. For example, if you turn to the activities of local governments, you can find the following relationship. Thus, today agreements on socio-economic partnership are concluded between business entities, in particular, agribusiness and

8 M. Heyder \& L. Theuvsen. Corporate Social Responsibility in Agribusiness: Empirical Findings from Germany. 113TH SEMINAR EUROPEAN ASSOCIATION OF AGRICULTURAL EConomists. September 3-6, 2009, Chania, Crete, Greece. Available at: https://doi. org/10.22004/ag.econ.58152.

9 Y. Chala. Social Responsibility of Enterprises as a Basis for Innovative Development of the Modern Economy. PROBLEMS AND PROSPECTS OF DEVELOPMENT OF THE BANKING SYSTEM OF UKRAINE 40. 2014. Pg. 276. 
local governments. These agreements are concluded considering the public interests in the field of integrated socio-economic development of the territorial community. In accordance with the basic principles of socio-economic agreements, the parties undertake to work together to improve the living standards of the population, and improve the welfare and social infrastructure of the united territorial community. ${ }^{10}$ These agreements are adopted within the Law of Ukraine "On local self-government in Ukraine"."11

It should be noted that corporate social responsibility is practically not regulated by Ukrainian legislation. However, international and European law regulates this issue. By its nature, the corporate social responsibility is a certain type of social obligations implemented in corporate governance (mostly voluntary) to employees, partners, civil society institutions and society as a whole. ${ }^{12}$ It arises as a result of the development of a business standard by international organizations. Thus, various initiatives at the international level, such as those of the United Nations, the Organization for Economic Co-operation and Development and the International Labor Organization, highlight the responsibilities of companies to act responsibly and respect human rights.

In particular, the United Nations Global Compact supports companies in doing business responsibly by aligning their strategies and operations with the United Nations Ten Principles on Human Rights, Labor, the Environment and the Fight against Corruption (United Nations Guiding Principles). It also supports companies in taking strategic actions that contribute to the achievement of broader social goals, such as the United Nations Sustainable Development Goals. ${ }^{13}$

It should be emphasized that the International Organization for Standardization has developed an international standard for corporate social responsibility - Iso 26000:2010. It sets out guidelines for management on how businesses and organizations can operate in a socially responsible manner, understanding how to act within ethical standards to contribute to health and well-being of society. ${ }^{14}$

10 Socio-Economic Partnership Agreements. Available at: https://radmr.gov.ua/news/ 1573202211/; "On approval of the agreement on social economic partnership". Draft Decision of Lyhivska Village Council (Dnipropetrovsk Region). Available at: https:// lykhivska.otg.dp.gov.ua/ua/rishennya-gromadi/pro-zatverdzhennya-tipovoyi-ugodipro-socialne-ekonomichne-partnerstvo

11 Law of Ukraine "On Local Self-Government in Ukraine", dated May 27, 1997. № 280/97BP. Available at: https://zakon.rada.gov.ua/laws/show/280/97-\%D0\%B2\%D1\%80\#Text

12 A. Kolot. Corporate Social Responsibility: Evolution and Development of Theoretical Views. ECONOMIC THEORY 4. 2013. Pg. 7.

13 Corporate Social Responsibility and its Implementation into European Union Company Law. Pg. 8. Available at: https://www.europarl.europa.eu/RegData/etudes/STUD/ 2020/658541/IPOL_STU(2020)658541_EN.pdf

14 Y. Chala, supra, note 10. Pg. 277. 
The international standard Iso 26000:2010 defines seven principles of social responsibility:

1. Accountability - the organization must be responsible (accountable) for its impact on society and the environment;

2. Transparency - the organization should be transparent in its decisions and activities that affect society and the environment;

3. Ethical behavior - organizations must constantly behave ethically;

4. Respect for the interests of stakeholders - the organization should respect, take into account and respond to the interests of its stakeholders;

5. Compliance with the law - compliance with the rule of law is mandatory;

6. Observance of human rights;

7. Compliance with international standards of conduct.15

After analyzing international documents in the field of collective social responsibility, it should be noted that they can be used as the basis for the development of corporate social responsibility in Ukraine, in particular in the field of agribusiness.

\section{SOCIAL RESPONSIBILITY IN AGRIBUSINESS}

In Ukraine, the principles of social responsibility of agribusiness entities are laid down in the Concept for the implementation of state policy in the field of promoting the development of socially responsible business in Ukraine for the period up to 2030, approved by the order of the Cabinet of Ministers of Ukraine dated January 24, 2020 № 66-r.

According to this legislative act, the main areas of development of socially responsible business, implemented by economic entities on a voluntary basis, are:

- Environmental protection (introduction of innovative environmentally friendly and energy efficient technologies; prevention of negative environmental impact; waste disposal);

- Employment (creation of new jobs; publication of management reports; implementation of charitable activities aimed at supporting socially vulnerable groups; cooperation with educational entities to train and improve the skills of scientific and pedagogical workers; increase the level of 
professional training education seekers; promoting lifelong learning and supporting gifted youth);

- The development of labor relations (dialogue with trade unions, promoting collective agreements, creating opportunities for youth employment and facilitating access to education for workers, creating safe and ergonomic working conditions, conducting health and cultural activities, the introduction of modern management systems for occupational safety and health, the formation of a list of social guarantees, in particular for health insurance of employees in order to stimulate employment, etc.). ${ }^{16}$

Thus, it can be argued about the formation in Ukraine of areas of corporate social responsibility, which extends to agribusiness.

In summary, it should be noted that corporate social responsibility is a voluntary responsibility in the form of active actions of business entities in areas defined by international and national law, which is implemented considering the interests of business, society, community and consumers, in order to achieve a positive effect in the sphere of social, economic development of the state a whole, its regions, enterprises, etc.

Social responsibility is also a special independent direction of agribusiness development, as the relations of social development of the village (as part of the relations of responsibility) constitute an independent agrarian group of relations. ${ }^{17}$

It should be noted that researchers in the field of agrarian law turn more to the issue of social development of the rural areas. O. Gafurova points out that the policy of rural social development should consist of a set of measures aimed at ensuring social justice, namely: Gradual improvement of the standard and quality of life of the rural population, providing them with decent living conditions and guaranteeing constitutional rights to work, social protection, education, health care, culture, housing, etc. ${ }^{18} \mathrm{~V}$. Yermolenko explores the sustainable development of rural areas as a systematical formation of organizational, economic, political and legal measures aimed at ensuring proportional and simultaneous, irreversible and stable progressive changes

16 Order of the Cabinet of Ministers of Ukraine "On approval of the Concept for the implementation of state policy in the field of promoting the development of socially responsible business in Ukraine for the period up to 2030", dated January 24, 2020, № 66-p. Available at: https://zakon.rada.gov.ua/laws/show/66-2020-\%D1\%80\#Text

17 I. Kulchiy. ORGANIZATIONAL AND LEGAL SUPPORT FOR THE DIVERSIFICATION OF RURAL AREAS WITH THE PARTICIPATION OF AgRICULTURAL PRODUCERS. Kharkiv. (2015). P. 29.

18 O. Gafurova. Rural Social Development Policy: Legal Aspects. SCIENTIFIC BULLETIN OF THE NATIONAL UNIVERSITY OF LIFE AND ENVIRONMENTAL SCIENCES OF UKRAINE. LAW SERIES 3. 2012. Pg. 46. 
in productional, social and environmental spheres, which occur proportionally and simultaneously in each of the components of the rural area..$^{19}$ In his turn, A. Stativka draws attention to the sustainable development of rural areas, which represents a set of social relations for the stable development of the rural community, as well as it provides growth and efficiency of the agricultural sector, standard and quality of life, and improves the environmental situation in rural areas. ${ }^{20}$ Analyzing the above, it can be argued that doctrinal studies of social development of rural areas have become the basis for the formation of the concept of social responsibility of agribusiness.

It should be emphasized that the social responsibility of agribusiness in Ukraine is multi-vector, and in particular it includes: Job creation; support of rural medicine (medical and obstetric points, district hospitals); support of rural infrastructure (repairs of roads, schools, boarding schools, preschools, clubs, purchase of equipment); opening of computer classes in schools; reconstruction of churches; construction of social housing; development of dialogue with local communities (issue of corporate newspapers in the regions where companies are present; organization of a hotline); support for events dedicated to the celebration of national holidays and events of urban significance, exhibitions and festivals, organization of village days and field days; meetings, forums, round tables and conferences with representatives of universities and research institutes, educational, scientific, cultural and other institutions located in the region of the company; creation of charitable foundations; assistance to anti-terrorist operation participants and members of their families; support for local sports and cultural events; sponsorship of athletes, etc. ${ }^{21}$

In view of the above mentioned, it is really possible to argue that there is the dispersion of areas of social responsibility of agribusiness. This provision is due to the fact that the social responsibility of agribusiness: 1) Has not yet been the subject of research in the field of agrarian law; 2) the state tries to transfer social projects to agribusiness entities, sometimes getting rid of the burden of social responsibility; 3) the absence of a special system of legislative norms on the regulation of relations in the field of agribusiness.

As some researchers suggest, for the majority of large agribusiness entities corporate social responsibility has a non-permanent nature with inconsistent and

19 V. Yermolenko. Features of Formation of the Category "sustainable development of rural areas". SCIENTIFIC BULLETIN OF THE NATIONAL UNIVERSITY OF LIFE AND ENVIRONMENTAL SCIENCES OF UKRAINE. LAW SERIES 156. 2010. Pg. 57.

20 A. M. Stativka. (Ed.). CURRENT ISSUES OF AGRARIAN LAW OF UKRAINE: THEORY AND PRACTICE. FINN. (2010). Pg. 50.

21 T. Drabchuk \& O. Koval. The Role of Social Responsibility of Agribusiness in Ensuring Sustainable Development of Rural Areas. ECONOMY AND SOCIETY 18. 2018. Pg. 398. 
not a clear trend. It is often aimed at improving the reputation, without the desire to consider this aspect as long-termed and continuous. ${ }^{22}$ We can accept this point of view, because not all agribusiness entities focus their activities on the development of social responsibility.

Realization of social responsibility of the subject of agribusiness is a necessary direction of development of any subject. It should be noted that the implementation of this responsibility provides an opportunity to establish a dialogue with public authorities, local governments and the rural population. Today the social vector is the main tool for achieving market success and a powerful tool in ensuring a sufficient level of economic security for the company. ${ }^{23}$ The introduction of social responsibility in the activities of the relevant agribusiness entity emphasizes its stable development, indicates the prospects of its activities, and increases the level of trust to this entity.

The current problem is that, at this stage of their development, agricultural companies in Ukraine do not consider social responsibility as an effective tool to increase their investment attractiveness, although they recognize the need for its development. ${ }^{24}$ After all, it should be noted that the social responsibility of agribusiness should be reduced not only to the problems solved by private entities, but also to the participation in this process by government agencies, local governments. At the same time, at the present stage of agribusiness development, the balance of interests of the state and business should change. If earlier only the state took an active part in the development of the social sphere of rural areas, then over time some of the problems were transferred to agribusiness entities. However, there is still no clear system of balance of interests in the field of development and support of rural areas.

The state should be interested in supporting socially responsible agribusiness, which can affect the sustainable development of rural areas. The concept of sustainable development (including sustainable development of agriculture) is based on the unity and balanced development of three components - economic, environmental and social. ${ }^{25}$ These components provide an opportunity for stable operation of agribusiness in Ukraine. In particular, the economic development of agribusiness is

22 A. Suderkin. Social Responsibility of Agribusiness in Rural Development. INSTITUTIONAL REPOSITORY OF VADYM HETMAN KYIV NATIONAL ECONOMIC UNIVERSITY 29. 2017. Pg. 130.

23 Y. Danko \& N. Zaynalova. Social Responsibility of Agribusiness Entities in the System of Socio-Economic Protection of their Competitiveness. BULLETIN OF SUMY NATIONAL AGRARIAN UNIVERSITY. SERIES: ECONOMICS AND MANAGEMENT 4. 2016. Pg. 110.

24 L. Sus \& Y. Karpyshyn. Strategy of State Regulation of Social Responsibility of Agricultural Holdings. AccountING AND FINANCE 4. 2017. Pg. 163.

25 O. Mykhailenko. Sustainable Development of Agriculture: Theoretical Aspects. BULLETIN OF DNIPROPETROVSK UNIVERSITY. SERIES: WORLD ECONOMY AND INTERNATIONAL ECONOMIC RELATIONS 7. 2015. Pg. 53. 
based on the introduction of innovative technologies and on the use of new methods to increase production. At the same time, they are close to the environmental component, because the state of the environment, in most cases, depends on the latest technologies that ensure the safety of production for the environment.

In conclusion, it should be emphasized that the social responsibility of agribusiness is a promising area of agribusiness development. It can be considered as a voluntary obligation, in the form of active actions of agricultural producers for sustainable development of agricultural areas, in order to form a positive image, implement agricultural innovations, improve the quality of life of rural population, and protect the environment.

\section{CONCLUSIONS}

1. It is characterized that corporate social responsibility is a voluntary responsibility in the form of active actions of business entities in areas defined by international and national law, which is implemented considering the interests of business, society, community and consumers in order to achieve a positive effect in the sphere of social, economic development of the state as a whole, its regions, enterprises, etc.

2. It is formulated that in Ukraine the social responsibility of agribusiness has the following characteristics: 1) This responsibility has not yet become the subject of research in the field of agrarian law; 2) the state tries to transfer social projects to agribusiness entities, sometimes getting rid of the burden of social responsibility; 3) the absence of a special system of legislative norms on the regulation of relations in the field of agribusiness.

3. It is revealed that social responsibility of agribusiness is a voluntary obligation, in the form of active actions of agricultural producers for sustainable development of agricultural areas, in order to form a positive image, implement agricultural innovations, improve the quality of life of rural population, and protect the environment.

4. A promising area of research is to identify and solve problems that arise around corporate social responsibility and social responsibility of agribusiness entities. 


\section{REFERENCES}

A. M. Stativka. (Ed.). Current Issues of Agrarian LaW of Ukraine: Theory and Practice. finn. (2010).

A. Suderkin. Social Responsibility of Agribusiness in Rural Development. INSTITUTIONAL REPOSITORY of Vadym Hetman Kyiv National Economic University 29. 2017.

A. Kolot. Corporate Social Responsibility: Evolution and Development of Theoretical Views. ECONOMIC THEORY 4. 2013.

J. Sidneva \& T. Rybachuk-Yarova. Normative Basis of the Concept of Corporate Social Responsibility. Formation of MARKET RELATIONS IN UKRAINE 10. 2015.

I. Kulchiy. Organizational and Legal Support for the Diversification of RuRAL AREAS With the PARTicipation of Agricultural Producers. Kharkiv. (2015).

M. Heyder \& L. Theuvsen. Corporate Social Responsibility in Agribusiness: Empirical Findings from Germany. 113Th Seminar European Association of Agricultural Economists. September 3-6, 2009, Chania, Crete, Greece. Available at: https://doi.org/10.22004/ag.econ.58152.

M. I. Ortega, S. Sabo, P. Aranda Gallegos, J. E. Guernsey De Zapien, A. Zapien, G. E. Portillo Abril \& C. Rosales. Agribusiness, Corporate Social Responsibility, and Health of Agricultural Migrant Workers. Frontiers IN Public Health. 2016. Available at: https://doi.org/10.3389/ fpubh.2016.00054

L. Sus \& Y. Karpyshyn. Strategy of State Regulation of Social Responsibility of Agricultural Holdings. AcCOUNTING AND FINANCE 4. 2017.

O. Gafurova. Rural Social Development Policy: Legal Aspects. SCIENTIFIC BULLETIN OF THE NATIONAL University of LifE AND ENVIRONMENTAL SCIENCES OF UKRAINE. LAW SERIES 3. 2012.

O. Mykhailenko. Sustainable Development of Agriculture: Theoretical Aspects. BULLETIN OF DNiPROPETROVSK University. SERIES: World ECONOMY AND INTERNATIONAL ECONOMIC RELATIONS 7. 2015.

T. Drabchuk \& O. Koval. The Role of Social Responsibility of Agribusiness in Ensuring Sustainable Development of Rural Areas. ECONOMY AND SOCIETY 18. 2018.

T. Gagalyuk \& F. Schaft. Corporate Social ReSPonsibILITY IN AgRIBUsiness. Kyiv. (2016). 
Legal support of social responsibility of agribusiness entities of Ukraine

United Nations. Guiding PRInCIPLeS On BusinesS And HumAn RIGHTS. Un. (2011).

V. Yermolenko. Features of Formation of the Category "sustainable development of rural areas". SCIENTIFIC BULletin of the NATIONAL University of LifE AND ENVIRONMENTAL SCIENCES OF UKRAINE. LAW SERIES 156. 2010.

Y. Chala. Social Responsibility of Enterprises as a Basis for Innovative Development of the Modern Economy. Problems and Prospects of Development of the Banking System of Ukraine 40. 2014.

Y. Danko \& N. Zaynalova. Social Responsibility of Agribusiness Entities in the System of SocioEconomic Protection of their Competitiveness. Bulletin of Sumy NATIONAL Agrarian University. Series: EConomics And MAnagement 4. 2016.

Y. Kogotko. Poverty of the Rural Population of Ukraine. DemogRAPHY AND SOCIAL ECONOMY 23. 2015. 